\title{
Studies on the effect of sodium arsenate \& cadmium chloride on Pithophora oedogonia (Mont.) Wittrock 1877
}

\author{
Puspendu Karmakar, Jai Prakash Keshri* \\ Phycology Laboratory, Department of Botany, The University of Burdwan - 713104, West Bengal, India
}

Received: September 08, 2020 Revised: March 25, 2021 Accepted: March 30, 2021 Published: April 14, 2021

*Corresponding Author: Jai Prakash Keshri E-mail: keshrijp@gmail.com

\begin{abstract}
Cadmium and Arsenic are heavy metals although not common in our environment, its threat in certain places are aggravated due to anthropogenic factors. To know its critical role on plants the investigation was made using $\mathrm{Na}_{2} \mathrm{HAsO}_{4}$ and $\mathrm{CdCl}_{2}$ treatment on Pithophora oedogonia (Mont.) Wittrock 1877. The observations were made after 14 days of treatment. The changes were noted. In both cases, the treated cells exhibited gradual disruption of cell wall and cell membrane. The chlorophyll content initially increased and finally decreased due to the notable destruction of chloroplasts in both treated cells. A profuse number of akinetes were observed at $100 \mathrm{ppm}$ and $150 \mathrm{ppm}$ of $\mathrm{Na}_{2} \mathrm{HAsO}_{4}$ and $\mathrm{CdCl}_{2}$ treated media. Decrease in protein content was started at $100 \mathrm{ppm}$ in both cases. The lipid content initially decreased at $50 \mathrm{ppm}$ and at $100 \mathrm{ppm}$ lipid profile increased in terms of toleration to the $\mathrm{Na}_{2} \mathrm{HAsO}_{4}$ and $\mathrm{CdCl}_{2}$ stress. Pithophora oedogonia (Mont.) Wittrock 1877 exhibited more sensitivity to $\mathrm{CdCl}_{2}$ stress \& showing abrupt changes in chlorophyll-a and chlorophyll-b production. The carotenoid production shown more sensitivity in $\mathrm{Na}_{2} \mathrm{HAsO}_{4}$ stress. Total phenol production was decreased initially and at $200 \mathrm{ppm} \mathrm{CdCl}$, stress had shown significant enhancement than the control set but at the $200 \mathrm{ppm}$ of $\mathrm{Na}_{2} \mathrm{HAsO}_{4}$ shown inhibitory effect.
\end{abstract}

KEYWORDS: Algae, Arsenic, Cadmium, Lipid, Protein, Phenol, Pigment, Pithophora oedogonia

\section{INTRODUCTION}

Heavy metals are having high atomic weight. They are 5 times denser than water (Tchounwou et al., 2012). Nowadays, it is a serious issue to keep safe environment from two important biologically hazardous heavy metals viz. Arsenic (As) and Cadmium (Cd). Since heavy metals are non-biodegradable and hence can be separated out through different physical or chemical process (Jung et al., 2017). Arsenic can be found in different forms depending upon its oxidation state or valency which ranges from +3 to +5 . Arsenite with oxidation state +3 is more toxic than arsenate, which contains the oxidation state of +5 (Gupta, 2007). According to the World Health Organization (WHO, 2011), arsenic exhibit high toxicity in its inorganic form, that can be found in contaminated drinking water, food preparations from contaminated water, contaminated food crops etc. whereas cadmium is a byproduct mainly of mining origin, extracting and refining the zinc and least amount from lead and copper ores. Arsenic is a potent carcinogenic agent and can cause conjunctivitis, skin lesions and hard patches on the palms and feet; on the other hand, cadmium can damage the kidneys, lungs and livers by deposition and can exhibit chronic \& acute effects respectively (Rashid \& Mridha, 1998). Most importantly, cadmium deposition shows the longer half-lives in human body that sustains throughout lifetime (Andreae \& Klumpp, 1979). According to WHO's guideline value for arsenic and cadmium in drinking water should be lower than $10 \mu \mathrm{g} / \mathrm{L}$ and $3 \mu \mathrm{g} / \mathrm{L}$ respectively.

Algae exhibit high accumulative ability in case of arsenic and cadmium that accumulate it from nearby environment and can synthesize water-lipid soluble compounds (Bernard, 2008). Freshwater algae contain comparatively low amount of arsenic than marine algal species. A study on growth of Chlorella vulgaris in a pure culture showed that the growth is unaffected in $100 \mathrm{ppm}$ of arsenic (Maeda et al., 1983) and inhibits growth in cadmium at concentration of $7 \mathrm{ppm}$ (Cheng et al., 2016). The photosynthetic efficiency is hampered due to metal ion which effects on photosynthetic pigments \& photosynthetic enzymes etc (Singh et al., 2018). Küpper et al. (1995) proved that cadmium can damage the photosynthetic ability by incorporating it in chlorophyll and thus prevent photosynthetic light harvesting. In Dunaliella salina, it has been observed that $\beta$-carotene, water extractable carbohydrate \& fatty acids are increased with the rising concentration of arsenic in medium (Yamaoka et al., 1992). During the heavy metal stress, amount

Copyright: (C) The authors. This article is open access and licensed under the terms of the Creative Commons Attribution License (http://creativecommons.org/licenses/by/4.0/) which permits unrestricted, use, distribution and reproduction in any medium, or format for any purpose, even commercially provided the work is properly cited. Attribution — You must give appropriate credit, provide a link to the license, and indicate if changes were made. 
of phenol was observed higher in algae that recover or tolerate stress with the metal chelating ability and act as antioxidants (Michalak, 2006; Mira et al., 2002).

In the present study, an easily available Chlorophycean member Pithophora oedogonia has been tested for the effect of different concentrations of arsenic and cadmium stress. The alga was collected from the farm house of Burdwan University in Purba Barddhaman district. For this study, focus was made on changes of protein content, lipid content, pigment content and total phenol content.

\section{MATERIAL \& METHODS}

\section{Collection \& Identification of Algal Sample}

Algal sample was collected from the farm house of Burdwan University campus, Purba Bardhaman district in West Bengal. The geological location is $23^{\circ} 13^{\prime} 02.7^{\prime \prime} \mathrm{N} \& 87^{\circ} 50^{\prime} 58.4^{\prime \prime} \mathrm{E}$ taken by GARMIN GPSMAP 78S GPS location tracker device. Ecological parameters were analyzed from the water sample following standard protocol. The collected sample was washed properly in gentle running water and purity was checked microscopically. Depending upon the observation of morphological characteristics under microscope the sample was identified as Pithophora oedogonia (Mont.) Wittrock 1877.

\section{Preparation, Preservation and Media Culturing of the Sample}

After the purification of the sample, little amount of the sample Pithophora oedogonia was fixed in $4 \%$ formalin. Different grades of arsenic and cadmium were prepared in modified CHU 10 media. The arsenic and cadmium concentrations of $50 \mathrm{ppm}, 100 \mathrm{ppm}, 150 \mathrm{ppm}, 200 \mathrm{ppm}$ were made up by Sodium Arsenate $\left(\mathrm{Na}_{2} \mathrm{HAsO}_{4}\right)$ \& Cadmium Chloride $\left(\mathrm{CdCl}_{2}\right)$ respectively. $5 \mathrm{gm}$ of algal sample was weighted and put in each modified CHU 10 media of different arsenic and cadmium concentration for 14 days. Only CHU 10 media with $5 \mathrm{gm}$ of algal sample was treated as control and each experiment was repeated thrice. After the given period of time the Pithophora samples from different media were collected \& little amount of Pithophora sample was allowed to dry in air flow of normal room temperature for further study. Slides were prepared from different culture media of arsenic and cadmium concentration for changes of morphological study. Images were taken by Zeiss Axiostar Plus Microscope with Nikon DS 60 camera.

For permanent slides preparation, standard procedure was followed. Small portion of the sample was taken on a clean slide then it was covered by GFW solution as a mountant. After putting cover glass it was sealed with synthetic paint and then kept for drying.

\section{Ecological Data}

Ecological data of the studying sample Pithophora oedogonia at the time of collection was taken with the help of Multi-Parameter
PCSTestr $^{\mathrm{TM}} 35$ for ${ }_{\mathrm{P}}^{\mathrm{H}}$, electrical conductivity, total dissolved solute (TDS), salinity, temperature \& with the help of HiMedia Laboratories Pvt. Ltd. supplied test kits for other tests. Ecological data is shown in Table 1.

Table 1: Ecological data of the collection spot

\begin{tabular}{llc}
\hline 1. & PH & \\
2. & Temperature & 3.06 \\
3. & Total Dissolve Solute (TDS) & $32.3^{\circ} \mathrm{C}$ \\
4. & Salinity & $438 \mathrm{ppm}$. \\
5. & Electrical conductivity & $606 \mu \mathrm{ppm}$. \\
6. & Total dissolve Oxygen & $9 \mathrm{ppm}$. \\
7. & Alkanity & $110 \mathrm{ppm}$. \\
8. & Sulphate $\left(\mathrm{SO}_{4}\right)$ & $50 \mathrm{ppm}$. \\
9. & Arsenic $(\mathrm{As})$ & $\mathrm{Nil}$. \\
10. & Nitrite & $0.02 \mathrm{ppm}$. \\
11. & Nitrate & $10 \mathrm{ppm}$. \\
12. & Fluoride & $0.05 \mathrm{ppm}$. \\
13. & Free Chlorine & $\mathrm{Nil}$. \\
14. & Zinc $(\mathrm{Zn})$ & $\mathrm{Nil}$. \\
\hline
\end{tabular}

\section{Chlorophyll and Carotenoids Extraction \& Estimation}

$0.5 \mathrm{gm}$ of algal sample was taken to study and grinded with the help of motor \& pestle in $10 \mathrm{ml}$. of HPLC grade methanol. The homogenate was centrifuged for few minutes with REMI RM-12C micro centrifuge machine and the supernatant was kept in a measuring cylinder. This washing was repeated 3-4 times until the pellet lost its greenish colouration. Absorbances of algal extract were taken with the help of single beam L1-721 Microprocessor Visible Spectrophotometer (Lasany) at $663 \mathrm{~nm}$, $646 \mathrm{~nm} \& 470 \mathrm{~nm}$. Estimation of chlorophyll a, chlorophyll $\mathrm{b}$ and carotenoids were done by using following formulae (Lichtenthaler \& Wellburn, 1983).

Chlorophyll a $(\mu \mathrm{g} / \mathrm{ml})=12.21\left(\mathrm{~A}_{663}\right)-2.81\left(\mathrm{~A}_{646}\right)$

Chlorophyll b $(\mu \mathrm{g} / \mathrm{ml})=20.13\left(\mathrm{~A}_{646}\right)-5.03\left(\mathrm{~A}_{663}\right)$

Carotenoid $(\mathrm{ug} / \mathrm{ml})=\left(1000 \mathrm{~A}_{470}-3.27[\mathrm{chla}]-104[\mathrm{chl} \mathrm{b}]\right) / 229$

\section{Extraction \& Estimation of Total Soluble Protein}

Protein extraction was done by Barbarino \& Laurenco (2005) described method. In brief, lgm of dried algal sample was immersed in $4 \mathrm{ml}$. of distilled $\mathrm{H}_{2} \mathrm{O}$ for 12 hours and grinded with potter homogenizer. Washing and centrifugation at $4{ }^{\circ} \mathrm{C}$ (for 20 minutes at $15,000 \mathrm{~g}$ ) was done with another $4 \mathrm{ml}$. of distilled water where supernatant was collected and pellet was mixed with $\mathrm{lml}$. of assay grade $0.1 \mathrm{~N} \mathrm{NaOH}$ with $0.5 \%$ $\beta$-marcaptoethanol purchased from Hi-Media Laboratories Pvt. Ltd. The centrifugation was done with the help of REMI RM-12C micro centrifuge machine. Pellet mixture was again centrifuged at $21^{\circ} \mathrm{C}$ and supernatant was collected to combine with the previously collected supernatant for protein study. Protein estimation was done following Lowry et al. (1951) described method with the help of Folin-Ciocalteu. Absorbance was taken with single beam L1-721 Microprocessor Visible Spectrophotometer (Lasany) at 660nm. 


\section{Total Lipid Extraction \& Estimation}

Lipid extraction \& estimation was done according to Bligh \& Dyer (1959) described method. In brief, 1 gm of dried algal sample was immersed in HPLC grade methanol-chloroform mixture which was 20 times greater (w/v). Equal amount of 0.2 parts of the volume of crude extract, $0.9 \% \mathrm{NaCl}$ solution was added and allow it to separate into bi-phasic form of the mixture by standing. Upper phase was removed by siphoning in such a way that lower phase was not disturbed \& thus rinsing was done thrice with small amount of pure solvent (chloroform: methanol: $\mathrm{NaCl}$ ). At last, methanol was added to it and allowed the solution into monophasic. Finally, the mixture was evaporated with hot water bath $\&$ the amount of lipid was calculated Wensar weighing machine.

\section{Total Phenol Content Determination}

$0.5 \mathrm{gm}$ of dried algal sample was immersed with $10 \mathrm{ml}$ methanol for 24 hours. The methanol extract was filtered in another amber coloured vial, washed thrice \& then evaporated. Serial dilution of gallic acid was prepared up to concentration of $200 \mu \mathrm{g} / \mathrm{ml}$ from $0 \mu \mathrm{g} / \mathrm{ml} 0.2 \mathrm{ml}$. phenol extract was mixed with $0.8 \mathrm{ml}$ distilled water and $1 \mathrm{ml}$ Folin-Ciocalteu reagent (1:1). After 5 minutes $2 \mathrm{ml}$ of $7.5 \%$ Sodium carbonate was added to the sample mixture. Total phenol content was measured as described by Singleton et al. (1999) described method at $765 \mathrm{~nm}$.

\section{RESULTS \& DISCUSSION:}

\section{Observation of Morphological Changes}

After the fourteen days exposure to the different concentrations (50 ppm, $100 \mathrm{ppm}, 150 \mathrm{ppm}$ and $200 \mathrm{ppm}$ ) of sodium arsenate and cadmium chloride few morphological changes in cell wall, cell membrane, pigmentation, akinete formation etc. were observed under microscope in the algal sample. It was compared to the samples of control set. Both the sodium arsenate and cadmium chloride treated cells exhibited gradual disruption of cell wall and cell membrane. Cadmium Chloride had shown more efficiency than the sodium arsenate. The cell size gradually decreased with the increase of the concentrations of sodium arsenate and cadmium chloride in the culture media. At 200 ppm cadmium chloride the cells were found remarkably died.

The chlorophyll content initially increased and finally decreased due to the notable destruction of chloroplasts in both the cadmium chloride \& sodium arsenate treated cells.

Both the intercalary and terminal akinetes formation starts at 50 ppm concentration of sodium arsenate and cadmium chloride. A profuse number of akinetes were observed at $100 \mathrm{ppm}$, and $150 \mathrm{ppm}$ concentrations of sodium arsenate and cadmium chloride. But 200ppm cadmium chloride solution shows gradual destruction of the akinetes.

So, it is clear from the above mentioned observations that the alga shows sensitivity to both of sodium arsenate and cadmium chloride. 200 ppm concentration of cadmium chloride solution showed more toxic effects than the rest of the concentrations. Figure 1 shows the morphological changes under different stress conditions.

\section{Observation of Chlorophyll and Carotenoids Change}

After fourteen days treatment with sodium arsenate and cadmium chloride solution, the obtained results are shown in Figures 2-4 for chlorophyll-a, chlorophyll-b \& carotenoids respectively.

In sodium arsenate treated samples chlorophyll-a, chlorophyll-b and carotenoid contents were increased rapidly at $50 \mathrm{ppm}$ concentration \& then gradually decreased from $100 \mathrm{ppm}$ to 200 ppm which is below the control set. In case of cadmium chloride treated samples chlorophyll-a and chlorophyll-b slightly increased at $50 \mathrm{ppm}$ concentration and increased rapidly at 100 ppm concentration showing the highest value. After gradual decrease at 150 ppm concentration, suddenly chlorophyll-a concentration falls at $200 \mathrm{ppm}$ which shows much lower value

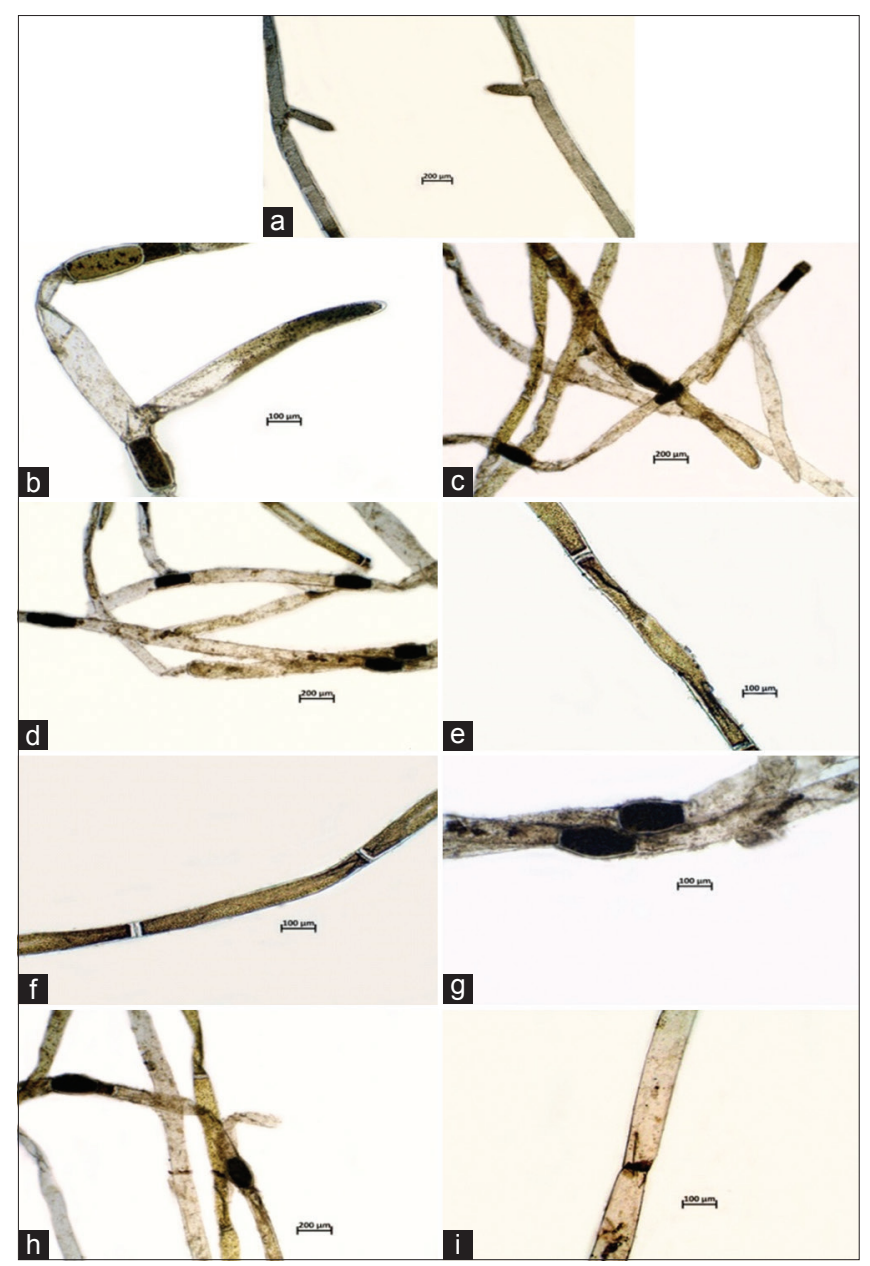

Figure 1: Observation of morphological changes : a- Control sample, b- 50 ppm of Sodium arsenate stress, c- 100 ppm of Sodium arsenate stress, d- 150 ppm of Sodium arsenate stress, e- 200 ppm of Sodium arsenate stress, f- 50 ppm of Cadmium chloride stress, g- 100 ppm of Cadmium chloride stress, h- 150 ppm of Cadmium chloride stress, $\mathrm{i}-200$ ppm of Cadmium chloride stress 
than the control set. Carotenoid value also decreased which is slightly lower than the control one.

\section{Observation of Total Soluble Protein Changes}

After fourteen days of treatment, changes in protein content were noted. In Sodium arsenate treated samples showed highest protein content at $50 \mathrm{ppm}$ concentration which is

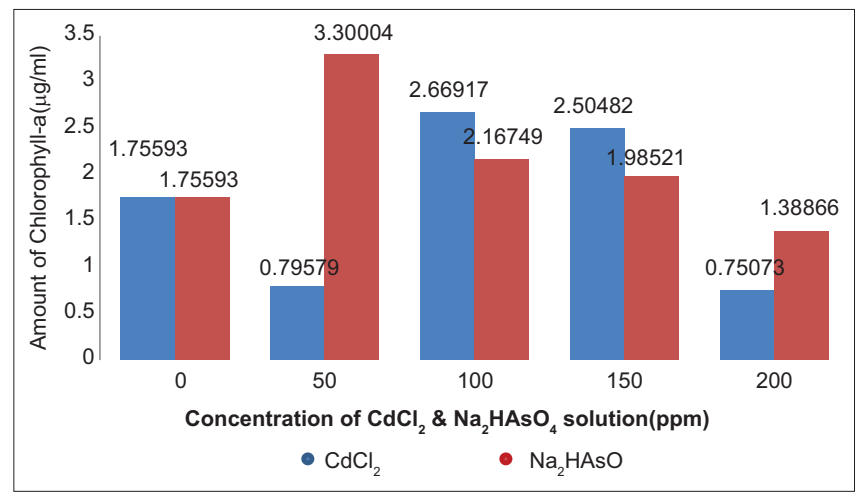

Figure 2: Chlorophyll-a content changes in Pithophora oedogonia treated with different grades of $\mathrm{CdCl}_{2} \& \mathrm{Na}_{2} \mathrm{HAsO}_{4}$ solution

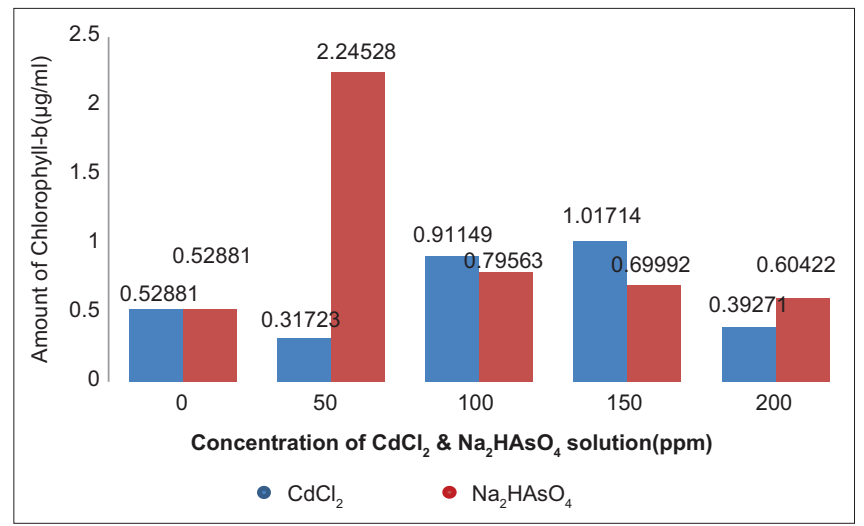

Figure 3: Chlorophyll-b content changes in Pithophora oedogonia treated with different grades of $\mathrm{CdCl}_{2} \& \mathrm{Na}_{2} \mathrm{HAsO}_{4}$ solution

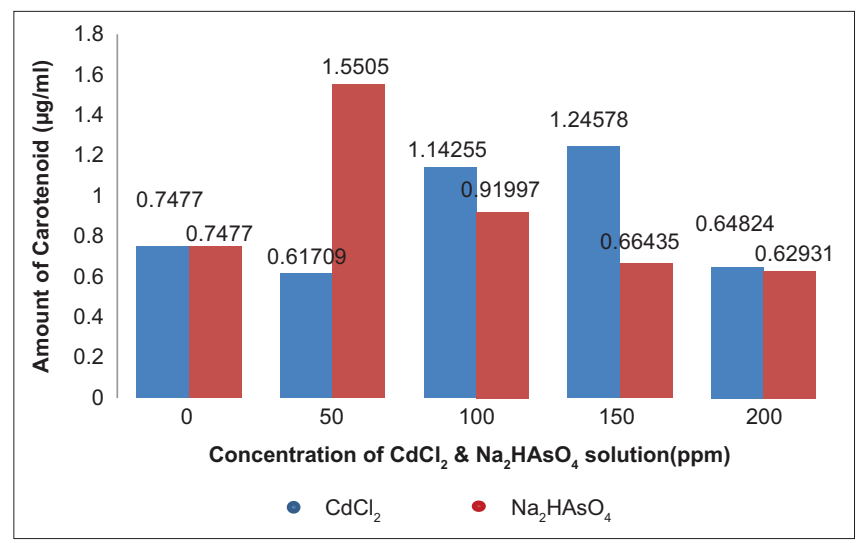

Figure 4: Carotenoid content changes in Pithophora oedogonia treated with different grades of $\mathrm{CdCl}_{2} \& \mathrm{Na}_{2} \mathrm{HAsO}_{4}$ solution even greater than the protein content of control sets. $100 \mathrm{ppm}$, $150 \mathrm{ppm}$ and $200 \mathrm{ppm}$ sodium arsenate concentration shows gradual decrease of protein content. In case of Cadmium chloride treated samples also shows higher protein content, but here sudden and rapid fall of the protein content takes place. Figure 5 shows the changes of total soluble protein with the treatments.

\section{Observation of Total Soluble Lipid Changes}

In both sodium arsenate and cadmium chloride treated samples at $50 \mathrm{ppm}$ concentration lipid content decreases, and this decrease of lipid content is lower in sodium arsenate treated samples than cadmium chloride treated samples. Both the 100 ppm concentration shows highest lipid content which is greater than control set. Lipid content gradually decreased from 150 ppm concentrations and $200 \mathrm{ppm}$ shows much decreased value than the control set. Figure 6 shows the changes of total lipid content with different treatment.

\section{Observation of Total Phenol Changes}

In sodium arsenate treated samples $50 \mathrm{ppm}$ concentration showed sudden decrease in phenolics contents; $100 \mathrm{ppm}$ and $150 \mathrm{ppm}$ concentrations shows gradual increase and $150 \mathrm{ppm}$

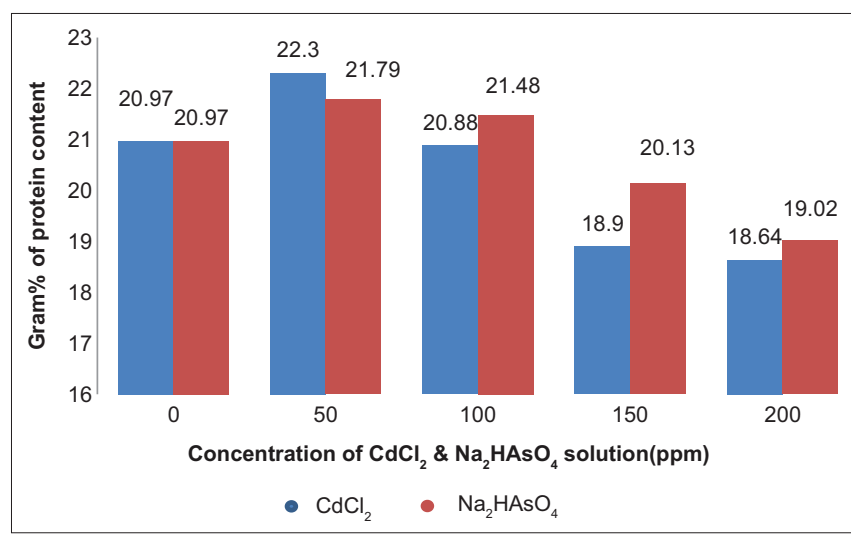

Figure 5: Protein content changes in Pithophora oedogonia treated with different grades of $\mathrm{CdCl}_{2} \& \mathrm{Na}_{2} \mathrm{HAsO}_{4}$ solution

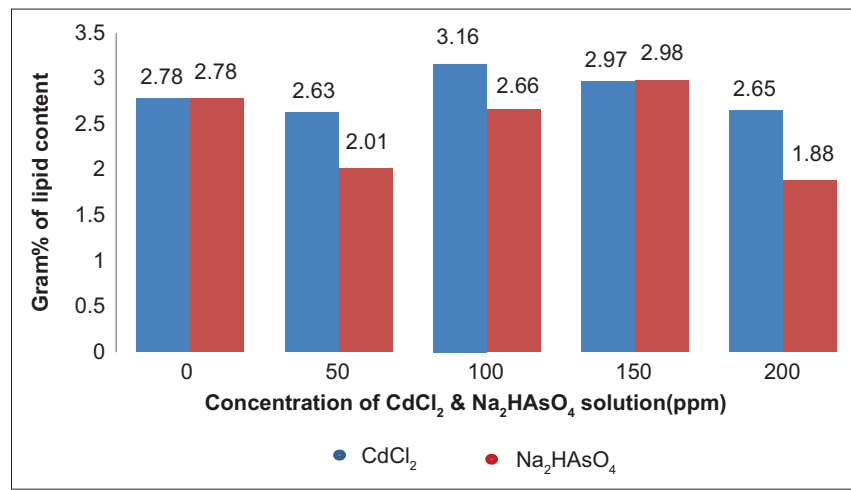

Figure 6: Lipid content changes in Pithophora oedogonia treated with different grades of $\mathrm{CdCl}_{2} \& \mathrm{Na}_{2} \mathrm{HAsO}_{4}$ solution 


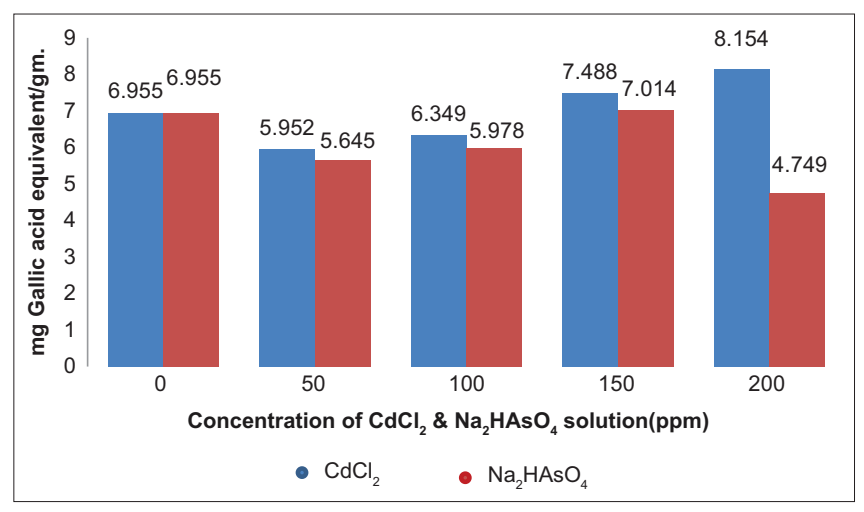

Figure 7: Phenol content changes in Pithophora oedogonia treated with different grades of $\mathrm{CdCl}_{2} \& \mathrm{Na}_{2} \mathrm{HAsO}_{4}$ solution

concentration shows highest phenolics content which is more than the control set. Phenolics content suddenly falls at the 200 ppm concentration. Figure 7 shows the changes of phenolics in different stress conditions.

\section{CONCLUSION}

After fourteen days sodium arsenate and cadmium chloride treatment on Pithophora oedogonia (Mont.) Wittrock 1877, the different changes in protein, lipid, pigments, total phenolics contents were noted, where, protein content decreasing starts at $100 \mathrm{ppm}$ concentration in both cases and the result shows that Cadmium chloride is more sensitive for protein synthesis than that of the sodium arsenate. The lipid content shows initially decreased a $50 \mathrm{ppm}$ concentration, at $100 \mathrm{ppm}$ lipid profile increasing to tolerate the As and Cd stress, where response rate noticed was more or less same in both the cases. Pithophora oedogonia (Mont.) Wittrock 1877 shown more sensitivity to Cadmium chloride stress showing abrupt changes in chlorophyll- a and chlorophyll-b production. The carotenoid production shows more sensitivity to As than the Cd stress. The total phenolics production was decreased initially at $50 \mathrm{ppm}$ conc. At 200 ppm Cd stress had shown significant increase in phenolics content than the control set. But the $200 \mathrm{ppm}$ of sodium arsenate shows inhibitory effect on the production of phenolics. This study shows the interactive role of the naturally occurring alga with hazardous chemicals. It forecasts the bioremediation or biosensor role of alga for next studies.

\section{REFERENCES}

Andreae, M. O., \& Klumpp, D. W. (1979). Biosynthesis and release of organoarsenic compounds by marine algae. Environmental Science \& Technology, 13, 738-741. https://doi.org/10.1021/es60154a001

Barbarino, E., \& Laurenco, S. O. (2005). An evaluation of methods for extraction and quantification of protein from marine macro- and microalgae. Journal of Applied Phycology, 17, 447-460. https://doi. org/10.1007/s10811-005-1641-4

Bernard, A. (2008). Cadmium \& its adverse effects on human health. Indian Journal of Medical Research, 128(4), 557-564.

Bligh, E. G., \& Dyer, W. J. (1959). A rapid method of total lipid extraction and purification. Canadian Journal of Biochemistry \& Physiology, 37(8), 911-917. https://doi.org/10.1139/y59-099

Cheng, J., Qiu, H., Chang, Z., Jiang, Z., \& Yin, W. (2016). The effect of cadmium on the growth and antioxidant response for freshwater algae Chlorella vulgaris. Springer Plus, 5(1), 1290. https://doi. org/10.1186/s40064-016-2963-1

Gupta, R. C. (2007). Veterinary Toxicology. (1 ${ }^{\text {st }}$ ed.). New York, US: Academic Press.

Jung, W., Park, Y. K.., An, J. S., Park, J. Y., \& Oh, H. J. (2017). Sorption of arsenic and heavy metals using various solid phase materials. International Journal of Environmental Science and Development, 8(2), 71-74. https://doi.org/10.18178/ijesd.2017.8.2.923

Küpper, H., Küpper, F., \& Spiller, M. (1996). Environmental relevance of heavy metal-substituted chlorophylls using the example of water plants. Journal of Experimental Botany, 47(2), 259-266. https://doi. org/10.1093/jxb/47.2.259

Lichtenthaler, H. K., \& Wellburn, A. R. (1983). Determinations of total carotenoids and chlorophylls $a$ and $b$ of leaf extracts in different solvents. Biochemical Society Transactions, 11(5), 591-592. https:// doi.org/10.1042/bst0110591

Lowry, O. H., Rosebrough, N. J., Farr, A. L., \& Randall, R. J. (1951). Protein measurement with the folin phenol reagent. Journal of Biological Chemistry, 193, 265-275. https://doi.org/10.1016/s00219258(19)52451-6

Maeda, S., Kumamoto, T., Yonemoto, M., Nakajima, S., Takeshita, T., Higashi, S., \& Ueno, K. (1983). Bioaccumulation of arsenic by freshwater algae and the application to the removal of inorganic arsenic from an aqueous phase. Part I. Screening of freshwater algae having high resistance to inorganic arsenic. Separation Science and Technology, 18(4), 375-385. https://doi. org/10.1080/01496398308068571

Michalak, A. (2006). Phenolic compounds and their antioxidant activity in plants growing under heavy metal stress. Polish Journal of Environmental Studies, 15(4), 523-530.

Mira, L., Fernandez, M. T., Santos, M., Rocha, R., Florencio, M. H., \& Jennings, K. R. (2002). Interactions of flavonoids with iron and copper ions: A mechanism for their antioxidant activity. Free Radical Research, 36(11), 1199-1208. https://doi.org/10.1080/1071576021000016463

Rashid, M., \& Mridha, M. A. K. (1998). Arsenic contamination of groundwater in Bangladesh. 24 th WEDC conference. (pp. 162-165).

Singh, V., Singh, S., Singh, R., \& Prasad, S. (2018). Environment and Photosynthesis: A Future Prospect. New Delhi, India: Studium Press.

Singleton, V. L., Orthofer, R., \& Lamuela-Raventos, R. M. (1999). Analysis of Total Phenols and Other Oxidation Substrates and Antioxidants by Means of Folin-Ciocalteu Reagent. Methods in Enzymology, 299, 152-178. https://doi.org/10.1016/s0076-6879(99)99017-1

Tchounwou, P. B., Yedjou, C. G., Patlolla, A. K., \& Sutton, D. J. (2012). Heavy metal toxicity and the environment. Molecular, Clinical and Environmental Toxicology, 101, 133-164. https://doi.org/10.1007/9783-7643-8340-4_6

World Health Organization. (2011). Arsenic in drinking water, Background document for development of WHO Guidelines for Drinking-water Quality (WHO document WHO/SDE/WSH/03.04/75/Rev/1). Retrieved from https://www.who.int/water_sanitation_health/dwq/chemicals/ arsenic.pdf?ua $=1$

Yamaoka, Y., Takimura, O., Fuse, H., \& Kamimura, K. (1992). Effects of arsenic on the organic component of the alga Dunaliella salina. Applied Organometallic Chemistry, 6(4), 357-362. https://doi. org/10.1002/aoc.590060408 